\title{
Blockade of the natriuretic peptide receptor guanylyl cyclase-A inhibits NF- $\kappa$ B activation and alleviates myocardial ischemia/reperfusion injury
}

\author{
Takehiko Izumi, ${ }^{1}$ Yoshihiko Saito, ${ }^{1}$ Ichiro Kishimoto, ${ }^{1}$ Masaki Harada, ${ }^{1}$ \\ Koichiro Kuwahara, ${ }^{1}$ Ichiro Hamanaka, ${ }^{1}$ Nobuki Takahashi, ${ }^{1}$ Rika Kawakami, ${ }^{1}$ \\ Yuhao Li, ${ }^{1}$ Genzo Takemura, ${ }^{2}$ Hisayoshi Fujiwara, ${ }^{2}$ David L. Garbers, ${ }^{3}$ \\ Seibu Mochizuki, ${ }^{4}$ and Kazuwa Nakao ${ }^{1}$
}

${ }^{1}$ Department of Medicine and Clinical Science, Kyoto University Graduate School of Medicine, Kyoto, Japan
2Second Department of Internal Medicine, Gifu University School of Medicine, Gifu, Japan
${ }^{3}$ Howard Hughes Medical Institute and University of Texas Southwestern Medical Center at Dallas, Dallas, Texas, USA
${ }^{4}$ Department of Cardiology, Jikei University School of Medicine, Tokyo, Japan

Address correspondence to: Yoshihiko Saito, Department of Medicine and Clinical Science, Kyoto University Graduate School of Medicine, 54 Shogoin Kawahara-cho, Sakyo-ku, Kyoto 606-8397, Japan.

Phone: 81-075-751-3180; Fax: 81-075-771-9452; E-mail: yssaito@kuhp.kyoto-u.ac.jp.

Received for publication January 2, 2001, and accepted in revised form May 31, 2001.

Acute myocardial infarction (AMI) remains the leading cause of death in developed countries. Although reperfusion of coronary arteries reduces mortality, it is associated with tissue injury. Endothelial P-selectin-mediated infiltration of neutrophils plays a key role in reperfusion injury. However, the mechanism of the P-selectin induction is not known. Here we show that infarct size after ischemia/reperfusion was significantly smaller in mice lacking guanylyl cyclase-A (GC-A), a natriuretic peptide receptor. The decrease was accompanied by decreases in neutrophil infiltration in coronary endothelial P-selectin expression. Pretreatment with HS-142-1, a GC-A antagonist, also decreased infarct size and P-selectin induction in wild-type mice. In cultured endothelial cells, activation of GC-A augmented $\mathrm{H}_{2} \mathrm{O}_{2}$-induced P-selectin expression. Furthermore, ischemia/reperfusion-induced activation of NF- $\mathrm{KB}$, a transcription factor that is known to promote P-selectin expression, is suppressed in GC-A-deficient mice. These results suggest that inhibition of GC-A alleviates ischemia/reperfusion injury through suppression of NF- $\mathrm{KB}$-mediated P-selectin induction. This novel, GC-A-mediated mechanism of ischemia/reperfusion injury may provide the basis for applying GC-A blockade in the clinical treatment of reperfusion injury.

J. Clin. Invest. 108:203-213 (2001). DOI:10.1172/JCI200112088.

\section{Introduction}

Although acute myocardial infarction (AMI) remains the leading cause of death in developed countries, advances in the treatment of ischemic heart diseases have led to a decrease in mortality over the past three decades. For instance, reperfusion of coronary arteries with thrombolytic agents (1) or angioplasty (2-4) markedly reduces mortality and improves left ventricular function in AMI. Nonetheless, reperfusion after even brief periods of ischemia is associated with pathological alterations that represent either an acceleration of processes initiated during ischemia, per se, or new changes initiated during the reperfusion (5-7).

Ischemia/reperfusion prompts a release of reactive oxygen species $(8)$, cytokines $(9,10)$, and other proinflammatory mediators that activate both neutrophils and coronary vascular endothelium. Such activation promotes the expression of adhesion molecules on both neutrophils and endothelium $(11,12)$, which recruits the former to the surface of the latter and initiates a specific cascade of cell-cell interactions, leading first to adherence of neutrophils to the endothelium and then to transendothelial migration and direct interaction with myocytes $(13,14)$. This reperfusion injury shares many characteristics with inflammatory responses in which neutrophils feature prominently. Atrial and brain natriuretic peptides (ANP and BNP, respectively) are hormones secreted from the heart that possess potent diuretic, natriuretic, and vasorelaxant activities. They exert their effects through activation of the guanylyl cyclase-A (GC-A) receptor, which leads to an increase in the intracellular second messenger, cGMP (15). We and others have shown previously that cardiac natriuretic peptide systems are rapidly activated (16-21), and plasma BNP concentrations are markedly elevated (22) after AMI. Although expression of the GC-A gene is known to occur in the ventricle (23, $24)$, virtually nothing is known about the intracardiac functions of natriuretic peptides in AMI.

We therefore used genetically engineered, GC-A-deficient mice and HS-142-1, a nonpeptide GC-A antagonist (25), to investigate the effects blocking endogenous natri- 
uretic peptide signaling on the size of myocardial infarcts evoked by protocols of ischemia and reperfusion.

\section{Methods}

Animals. GC-A-deficient $\left(G C-A^{-/}\right)$mice and their GC- $A^{+/+}$ littermates (wild-type controls) were generated as described previously (26). All mice used in this study were between 10 and 14 weeks old. C57BL/6 (10-14 weeks) mice were purchased from Shimizu Co. (Kyoto, Japan). All experimental procedures were performed according to Kyoto University standards for animal care. Surgical procedures. Mice were initially anesthetized with ether and placed on a warm pad maintained at $37^{\circ} \mathrm{C}$. The trachea of each mouse was cannulated with a polyethylene tube connected to a respirator (Shinano Co., Tokyo, Japan) with a tidal volume set at $0.6 \mathrm{ml}$ and a rate set at $110 / \mathrm{min}$. The mice were then anesthetized with $0.5-1.5 \%$ isoflurane for the remainder of the surgical procedure. After a 10-minute equilibration period, a left thoracotomy was performed between the fourth and fifth ribs. The pericardial sac was then removed, and the left anterior descending artery (LAD) was visualized under a microscope and ligated with a 7-0 silk suture using a snare occluder. To avoid injuring the $\mathrm{LAD}$, a small patch was attached to its surface. Ischemia and reperfusion were accomplished by first tightening the snare occluder and then loosening it. Significant electrocardiogram and color changes at the area at risk (AAR) were considered indicative of successful coronary occlusion and reperfusion. The silk suture was left in place, and chests of the mice were closed with 5-0 silk sutures. The animals were then weaned from the respirator, and the intratracheal tube was removed once they were breathing spontaneously and began to move.

Myocardial ischemia and reperfusion. GC- $A^{+/+}$controls and $G C-A^{-/-}$mice were subjected to 30 minutes of LAD ligation, followed by either 6 hours or 2 days of reperfusion. For HS-142-1 (HS) treatment, mice were intravenously injected with $3 \mathrm{mg} / \mathrm{kg}$ of HS 30 minutes before ligation of the LAD. As control, mice were injected with saline in the same dose. HS was a kind gift from Kyowa Hakko Co., (Tokyo, Japan).

Evaluation of ischemic AAR and infarct size. Two days after reperfusion, the AAR and infarct area were evaluated in the $\mathrm{GC}-A^{+/+}$and $\mathrm{GC}-A^{-/-}$mice. The thoracotomies were reopened, the LADs reoccluded, and $1 \mathrm{ml}$ of $1.0 \%$ Evans blue (Sigma Chemical Co., St. Louis, Missouri, USA) was injected from the apex of each heart to delineate the nonischemic tissue. The hearts were then excised, washed with PBS, and cut into five transverse slices. The slices were then placed in a 96-well culture plate, stained for 15 minutes at room temperature with $1.0 \mathrm{ml}$ of $1.5 \%$ 2,3,5-triphenyltetrazolium chloride (TTC; Sigma Chemical Co.) solution to determine the infarct area, weighed, and photographed under a microscope (Olympus Co., Tokyo, Japan). Left ventricular (LV) area, AAR, and infarct were determined by computerized planimetry using NIH Image (v 1.57) software (Bethesda, Maryland, USA.). Infarct weights were calculated as: $\left[\left(A_{1} \times W_{1}\right)+\right.$
$\left.\left(A_{2} \times W_{2}\right)+\left(A_{3} \times W_{3}\right)+\left(A_{4} \times W_{4}\right)+\left(A_{5} \times W_{5}\right)\right]$, where $A$ is the area of infarct for the slice denoted by the subscript and $W$ is the weight of the respective section. The weight of the AAR was calculated in similar fashion. Infarct was expressed as a percentage of the AAR and LV. Areas were determined independently by three observers blinded to the treatment protocol.

Histology. To determine the numbers of infiltrating polymorphonuclear neutrophils (PMNs), slices treated as described above were fixed in $4 \%$ paraformaldehyde at $4^{\circ} \mathrm{C}$, embedded in paraffin, cut into $4-\mu \mathrm{m}$ sections, and transferred to silicon-coated slides. The tissue sections were then stained with hematoxylin and eosin (H\&E) or Giemsa. The numbers of PMNs per highpower microscope field $(\times 400)$ were independently counted by two observers blinded to the treatment protocol. Average numbers of PMNs were obtained by randomly counting more than ten fields.

Myeloperoxidase activity. Neutrophil emigration was assessed by measuring myeloperoxidase (MPO) activity (27). Each heart was divided into infarct and noninfarct areas, after which the respective areas were homogenized and sonicated in $50 \mathrm{mmol} / \mathrm{l}$ potassium phosphate buffer, pH 6 , containing $0.5 \%$ hexadecyltrimethylammonium bromide (HTAB). The mixture was then centrifuged at $12,500 \mathrm{~g}$ for 30 minutes at $4^{\circ} \mathrm{C}$. The supernatant was collected into another tube and mixed with reaction buffer $(0.167 \mathrm{mg} / \mathrm{ml}$ of $o$-dianisidine dihydrochloride and $0.0005 \% \mathrm{H}_{2} \mathrm{O}_{2}$ in $50 \mathrm{mmol} / \mathrm{l}$ phosphate buffer, pH 6). Absorbance of these mixtures at $460 \mathrm{~nm}$ was measured using spectrophotometer, with the rate of change in absorbance being related to MPO activity. One unit of MPO activity was defined as that hydrolyzing $1 \mathrm{mmol}$ of peroxidase per minute at $25^{\circ} \mathrm{C}$.

Immunohistochemistry. Sections obtained as described above were treated with $3 \% \mathrm{H}_{2} \mathrm{O}_{2}$ to block endogenous peroxidase and then incubated for 1 hour at room temperature with rabbit polyclonal anti-P-selectin $\mathrm{Ab}$ (PharMingen, San Diego, California, USA) at a dilution of 1:200. The sections were then incubated with biotinylated rabbit IgG (DAKO, Tokyo, Japan), and Abbinding sites were visualized as an avidin-biotin peroxidase complex using 3-amino-9-ethyl carbazole (AEC).

Western blot analysis. Left ventricles were homogenized using a polytron homogenizer and sonicated in lysis buffer $(20 \mathrm{mmol} / \mathrm{l}$ Tris, $150 \mathrm{mmol} / \mathrm{l} \mathrm{NaCl}, 1 \mathrm{mmol} / \mathrm{l}$ EDTA, $1 \mathrm{mmol} / \mathrm{l}$ EGTA, $1 \%$ Triton X-100, $2.5 \mathrm{mM}$ sodium pyrophosphate, $1 \mathrm{mmol} / 1 \beta$-glycerolphosphate, 1 $\mathrm{mmol} / 1 \mathrm{Na}_{3} \mathrm{VO}_{4}, 1 \mu \mathrm{g} / \mathrm{ml}$ leupeptin, and $1 \mathrm{mmol} / \mathrm{l}$ PMSF). The resultant mixture was centrifuged at 25,000 $\mathrm{g}$ for 5 minutes, the supernatant collected, and the total protein concentration was determined using a standard protein assay (Bio-Rad Laboratories Inc., Hercules, California, USA). Samples containing approximately $100 \mu \mathrm{g}$ of protein were then subjected to $7.5 \%$ SDS-PAGE in TrisTricine SDS buffer, after which the gels were transferred electrically to Sequi-Blot PVDF membranes (Bio-Rad Laboratories Inc.). Membranes were then blocked for 1 hour at room temperature in Tris-buffered saline con- 
taining $1 \%$ Tween 20 (TBS-T) and 5\% nonfat milk. They were then incubated for 1 hour with gentle agitation at room temperature with rabbit polyclonal anti-P-selectin $\mathrm{Ab}$ in TBS-T (1:1000 dilution), washed three times with TBS-T, and incubated with horseradish peroxidase-conjugated (HRP-conjugated) anti-rabbit secondary $\mathrm{Ab}$ (DAKO) for 1 hour at room temperature. After four to five washes with TBS-T, the proteins were visualized using Renaissance enhanced chemiluminescent reagents (NEN Life Science Products Inc., Boston, Massachusetts, USA), and the membranes were autoradiographed.

Isolation of nuclear extracts. Nuclear extracts were prepared from frozen myocardial tissue as described previously $(28,29)$. Tissue samples were rinsed three times with ice-cold $\mathrm{Ca}^{2+}$-free and $\mathrm{Mg}^{2+}$-free $\mathrm{PBS}$, and then homogenized in $3 \mathrm{ml}$ of ice-cold buffer A (10 mmol/l HEPES, pH 7.9, $1.5 \mathrm{mmol} / 1 \mathrm{MgCl}_{2}, 10 \mathrm{mmol} / 1 \mathrm{KCl}, 1$ $\mathrm{mmol} / \mathrm{l}$ DTT, and $1 \mathrm{mmol} / \mathrm{l}$ PMSF) using a Dounce homogenizer. Human umbilical vein endothelial cells (HUVECs) were detached with 0.5\% EDTA, rinsed twice with PBS, and incubated with buffer $A$ in a centrifuge tube. The homogenate was transferred to a centrifuge tube. After a 10-minute incubation on ice, the homogenate was centrifuged at $850 \mathrm{~g}$ for 10 minutes at $4^{\circ} \mathrm{C}$. The cell pellet was suspended in ice-cold buffer $B$ $(0.1 \%$ Triton X-100 in buffer $A)$, incubated on ice for 10 minutes, and then centrifuged again as above. The resultant nuclear pellet was rinsed once with buffer $\mathrm{A}$, resuspended in buffer C $(20 \mathrm{mmol} / \mathrm{l}$ HEPES, $\mathrm{pH} 7.9$, $25 \%$ glycerol vol./vol., $0.42 \mathrm{~mol} / \mathrm{l} \mathrm{NaCl}, 1.5 \mathrm{mmol} / 1$ $\mathrm{MgCl}_{2}, 0.2 \mathrm{mmol} / 1 \mathrm{EDTA}, 0.5 \mathrm{mmol} / \mathrm{l}$ DTT, and 1 $\mathrm{mmol} / \mathrm{l} \mathrm{PMSF}$ ), and incubated on ice for 30 minutes. Nuclear proteins were obtained by centrifugation at $20,000 \mathrm{~g}$ for 15 minutes at $4^{\circ} \mathrm{C}$. The protein concentrations were determined as described above.

Electrophoretic mobility shift assay. A double-stranded oligonucleotide containing the consensus-binding sites for NF- $\kappa B\left(5^{\prime}\right.$-GATCGAGGGGACTTTCCCTAGC- $\left.3^{\prime}\right)$ was end-labeled with $\left[\gamma^{-32} \mathrm{P}\right]$ ATP (Amersham Pharmacia Biotech, Piscataway, New Jersey, USA) using T4 polynucleotide kinase. The reaction mixture was then incubated with $10 \mu \mathrm{g}$ of nuclear protein for 30 minutes, loaded onto $5 \%$ polyacrylamide gel, and electrophoresed at $250 \mathrm{~V}$ in $0.5 \times$ Tris-borate EDTA buffer. The gels were dried using a Gel-Drier and radiographed, after which the binding bands were semiquantified by scanning densitometry.

Competition experiments were performed to assess the specificity of NF- $\mathrm{KB}$-binding activity determined by electrophoretic mobility shift assay (EMSA). Nuclear extracts were incubated with unlabeled double-stranded NF- $\kappa B$ oligonucleotides for 5 minutes and then with labeled NF-KB oligonucleotides for an additional 30 minutes. Ab supershift assays were then performed to confirm that apparently bound NF- $\mathrm{KB}$ contained the p50 subunit. The labeled reaction mixture was incubated for 30 minutes; then $2 \mu \mathrm{g}$ of anti-p50 Ab was added. After incubation for an additional 2 hours at $4^{\circ} \mathrm{C}$, samples were run on polyacrylamide gels. a
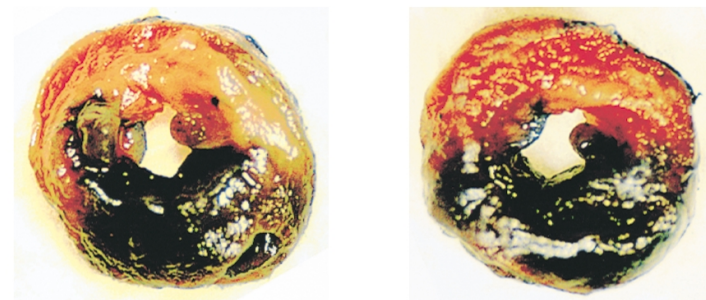

b
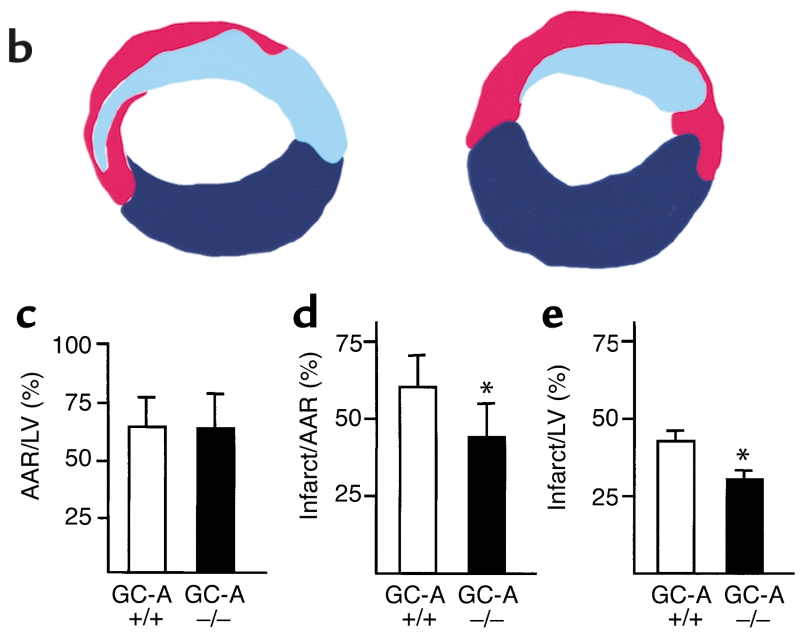

\section{Figure 1}

Evaluation of infarct size and AAR in hearts from GC- $A^{+/+}$and $G C-A^{-/-}$ mice subjected to 30 minutes of ischemia and 2 days of reperfusion. (a) Representative photographs of midventricular myocardial tissue from GC- $A^{+/+}$and GC- $A^{-/-}$mice. Note that the infarct area (white color) in the GC- $A^{-/-}$mouse is smaller than that in the GC- $A^{+/+}$mouse. (b) Schema of photographs of a. Infarct area is expressed as light blue, AAR is red, and nonischemic area is blue. (c) There was no significant difference in myocardial AAR/LV ratios in GC- $A^{+/+}$and $G C-A^{-/-}$mice. (d) Myocardial infarct/AAR ratios in GC- $A^{-/-}$mice were significantly smaller than in GC- $A^{+/+}$mice. (e) Infarct/LV ratios in GC- $A^{-/-}$mice were significantly smaller than in GC- $A^{+/+}$mice. ${ }^{*} P<0.05 \mathrm{vs}$. GC- $A^{+/+}$mice.

Radioimmunoassay. Ventricular ANP and BNP concentrations were measured by our specific radioimmunoassays (RIAs) reported previously (30). Tissue cGMP concentration was measured by Yamasa Cyclic GMP Assay Kit (Yamasa Co., Chiba, Japan).

Cell cultures. HUVECs and EBM-2 culture medium were purchased from Sanko Jyunyaku (Tokyo, Japan). The cells were plated into $75-\mathrm{cm}^{2}$ culture dishes (Becton Dickinson and Co., Franklin Lakes, New Jersey, USA) and maintained in EBM-2 medium supplemented with $2 \%$ FBS under a humidified atmosphere of $5 \%$ $\mathrm{CO}_{2} / 95 \%$ air at $37^{\circ} \mathrm{C}$. The medium was renewed every 2 days. Subcultures were obtained by treating the HUVEC cultures with $0.25 \%$ trypsin $/ 0.01 \%$ EDTA at $37^{\circ} \mathrm{C}$ for 5 minutes. Subconfluent HUVECs from passages five through eight were used in all experiments.

Cell culture protocol. To examine the effects of ANP and GC-A, HUVECs were exposed for 1 hour or 6 hours to the indicated doses of $\mathrm{H}_{2} \mathrm{O}_{2}$ alone or in combination with ANP $\left(10^{-8} \mathrm{M}\right.$ or $\left.10^{-6} \mathrm{M}\right)$, in the presence or the absence of $100 \mu \mathrm{g} / \mathrm{ml} \mathrm{HS}$. 

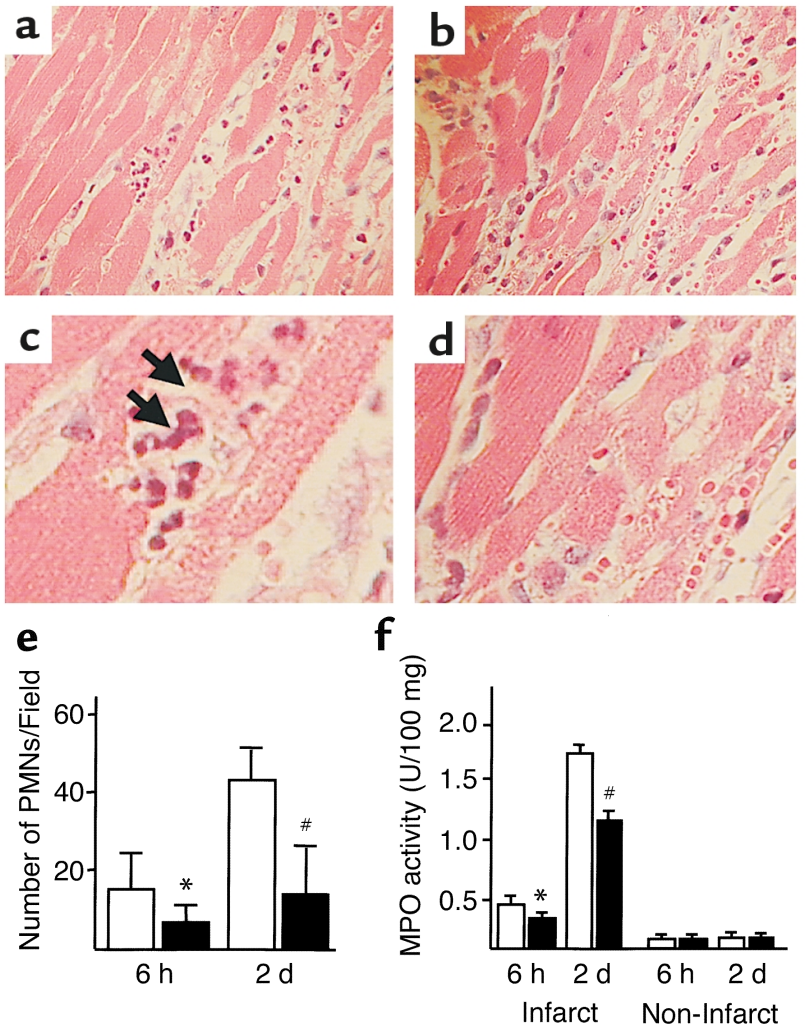

\section{Figure 2}

PMN infiltration in GC- $A^{+/+}$and GC- $A^{-/-}$mice subjected to myocardial ischemia/reperfusion. (a-d) H\&E staining of myocardial tissue from GC- $A^{+/+}$and GC- $A^{-/-}$mice obtained after 30 minutes of ischemia and 2 days of reperfusion. (a and $\mathbf{c}$ ) Perinecrotic area of a $G C-A^{+/+}$mouse at magnification of $\times 100$ and $\times 400$, respectively. ( $b$ and d) Perinecrotic area of a GC- $A^{-/-}$mouse at magnifications of $\times 100$ and $\times 400$, respectively. Note that significant numbers of PMNs accumulated in perinecrotic areas of GC- $A^{+/+}$mice, while a fewer PMNs infiltrated the GC- $A^{-/-}$heart. (e) Average numbers of infiltrating PMNs per $\times 400$ field in the myocardium subjected to 30 minutes of ischemia and either 6 hours or 2 days of reperfusion. After both 6 hours or 2 days of reperfusion, PMN numbers were significantly lower in GC- $A^{-/-}$mice (filled bars) than in time-matched GC- $A^{+/+}$controls (open bars). ${ }^{*} P<0.01$ vs. 6 hours of reperfusion in GC- $A^{+/+}$mice. ${ }^{\#} P<0.01$ vs. 2 days of reperfusion in GC- $A^{+/+}$mice. (f) Myocardial MPO activity in infarct and noninfarct cardiac tissue samples obtained from GC- $A^{+/+}$(open bars) and GC- $A^{-/-}$mice (filled bars) after 30 minutes of ischemia and 6 hours or 2 days of reperfusion. MPO activity is expressed as $\mathrm{U} / 100 \mathrm{mg}$ wet tissue weight, which was decreased significantly in the infarct areas of GC- $A^{-/-}$mice. ${ }^{*} P<0.05$ vs. 6 hours of reperfusion in GC- $A^{+/+}$mice. ${ }^{\#} P<0.01$ vs. 2 days of reperfusion in GC- $A^{+/+}$mice.

ELISA. To assess cell surface expression of P-selectin, HUVECs cultured in 96-well plates were incubated for 1 hour with the indicated medium, washed twice with PBS, and fixed for 15 minutes with $1 \%$ paraformaldehyde. To determine total P-selectin expression, the cells were incubated for 6 hours with the indicated medium and fixed in ethanol to permeabilize their membranes $(31,32)$, washed twice with PBS, fixed for an additional 30 minutes in ethanol, and incubated for 1 hour in a $2 \%$ BSA-HBSS solution. The cells were then incubated for
2 hours with mouse monoclonal anti-human P-selectin $\mathrm{Ab}$ (1:500 dilution; DAKO), followed by incubation for 1 hour with peroxidase-conjugated anti-mouse secondary $\mathrm{Ab}$ (1:2000 dilution; $\mathrm{DAKO})$, and then for $30 \mathrm{~min}$ utes with $100 \mu \mathrm{l} /$ well of substrate chromogen $\left(3,3^{\prime}, 5,5^{\prime}\right.$ tetramethylbenzidine). All incubations were performed at room temperature. Chromophore development was determined by measuring OD at $650 \mathrm{~nm}$ with a Spectramax microplate reader. Background absorbance was determined using cells incubated without primary Ab's.

Detection of intracellular peroxides with ANP. HUVECs were incubated with normal medium, $10^{-8} \mathrm{M}$ ANP, and $10^{-6} \mathrm{M}$ ANP for 1 hour. As a control, HUVECs were incubated with $100 \mu \mathrm{M} \mathrm{H}_{2} \mathrm{O}_{2}$. HUVECs were detached from the culture plate with $0.5 \%$ EDTA. To determine intracellular peroxides, endothelial cells were incubated with 5- (and-6) carboxy-2', $7^{\prime}$-dichlorodihydrofluorescein diacetate (carboxy- $\mathrm{H}_{2} \mathrm{DCFDA}$ ) (Molecular Probes Inc., Eugene, Oregon, USA). Approximately 10,000 cells were analyzed by flow cytometry to determine the oxidation of carboxy- $\mathrm{H}_{2}$ DCFDA that occurs during oxidative stress, according to the previous report by Bass et al. (33).

Cell viability. Mitochondrial respiration was assessed as a function of the mitochondria-dependent reduction of WST-8 (2-(2-methoxy-4-nitrophenyl)-3-(4nitrophenyl)-5-(2,4-disulfophenyl)-2H-tetrazolium, monosodium salt) to formazan. Cells plated in 96-well plates were incubated for 1 hour at $37^{\circ} \mathrm{C}$ with WST-8 $(0.5 \mathrm{mmol} / \mathrm{l})$. The extent of the reduction of WST- 8 to formazan was quantified by measuring OD at $450 \mathrm{~nm}$. Statistical analyses. All values are expressed as means \pm SEM. Statistical analysis of the data was performed by Student's $t$ test. ANOVA with post hoc Duncan tests were used to determine the significance of differences in multiple comparisons. $P$ values less than 0.05 were considered significant.

\section{Results}

Upregulation of ventricular ANP and BNP concentration and GC-A activity during myocardial ischemia/reperfusion in mice. We measured tissue levels of ANP and BNP in the ventricle after ischemia-reperfusion by RIA. As shown in Table 1, before ischemia/reperfusion the levels of ventricular ANP and BNP were $12.3 \pm 2.7$ $\mathrm{ng} / \mathrm{g}$ and $38.9 \pm 5.8 \mathrm{ng} / \mathrm{g}$, respectively, which are about 100-fold higher than those of circulating ANP and BNP in mice. In mice treated with 30 minutes of ischemia followed by 6 hours of reperfusion, ventricular ANP and BNP levels were approximately three times higher than those in sham-operated mice. The ventricular BNP level continued to increase until 2 days after reperfusion, while ventricular ANP level tended to decrease slightly. Next, to examine whether ANP and BNP act on in the ventricle, we measured ventricular cGMP concentration during ischemia/ reperfusion in mice. In 2 days of reperfusion, ventricular cGMP levels were elevated significantly compared with those in sham-operated mice $(13.3 \pm 0.9$ $\mathrm{pmol} / \mathrm{g}$ in operated mice and $9.7 \pm 0.9 \mathrm{pmol} / \mathrm{g}$ in 

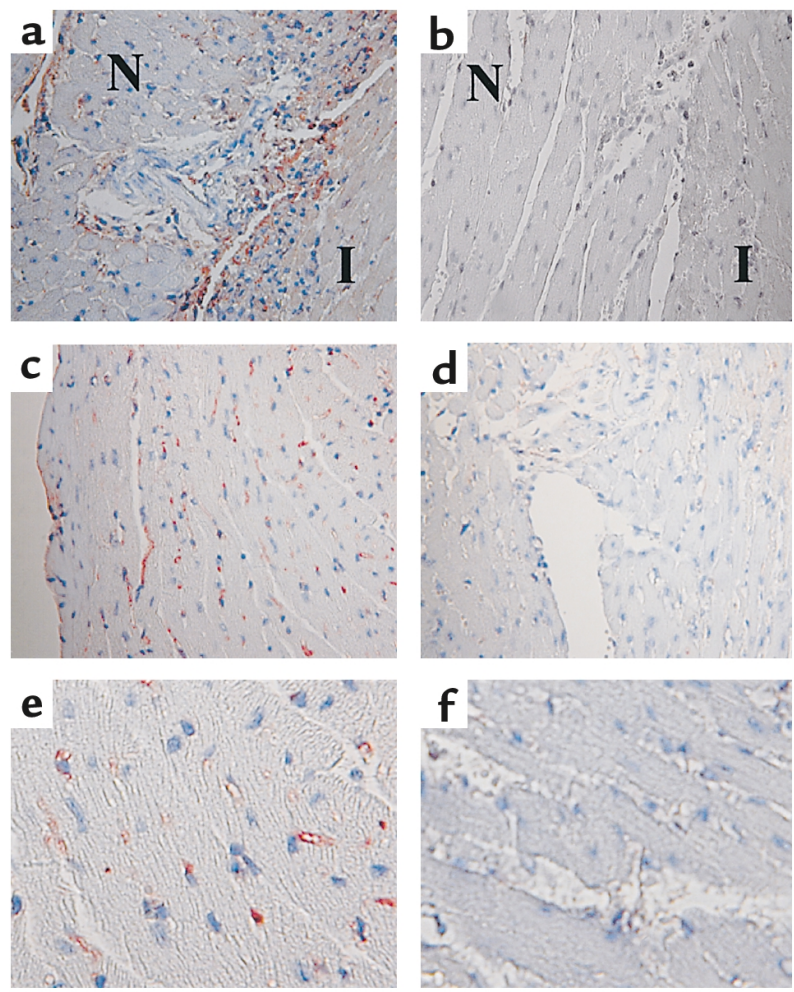
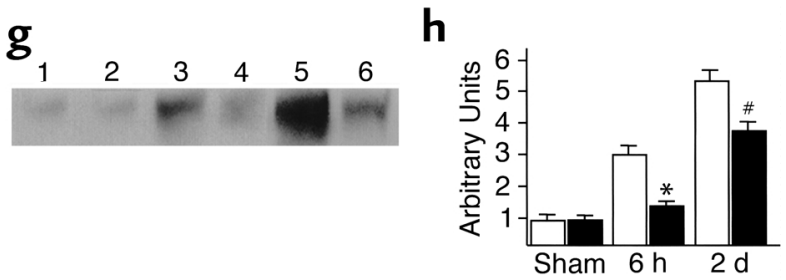

\section{Figure 3}

P-selectin expression in GC- $A^{+/+}$and GC- $A^{-/-}$mice during myocardial ischemia/reperfusion. (a-f) Immunolabeling of P-selectin in hearts from GC- $A^{+/+}(\mathbf{a}, \mathbf{c}$, and $\mathbf{e})$ and $G C-A^{-/-}$mice $(\mathbf{b}, \mathbf{d}$, and $\mathbf{f}) ; \mathrm{N}$, noninfarct tissue; I, infarct tissue. (a and $\mathbf{b}$ ) Border zones between necrotic and nonischemic areas. (c and $\mathbf{d}$ ) Perinecrotic areas. (e and f) High-power fields of perinecrotic areas. Levels of endothelial Pselectin expression in the border zones and in the centers of ischemic areas were lower in GC- $A^{-/-}$hearts. (g) Western blot analysis showing P-selectin expression in LV of GC- $A^{+/+}$(lanes 1, 3, and 5) and GC- $A^{-1-}$ (lanes 2, 4, and 6$)$ mice after 30 minutes of ischemia and 6 hours (lanes 3 and 4 ) or 2 days (lanes 5 and 6 ) of reperfusion. Lanes 1 and 2 show P-selectin expression without ischemia/reperfusion. (h) Semiquantitative analysis of P-selectin expression. P-selectin expression was significantly lower in GC- $A^{-/-}$mice (filled bars) than in GC- $A^{+/+}$mice (open bars) after 6 hours or 2 days of reperfusion. ${ }^{*} P<0.01$ vs. 6 hours of reperfusion in GC- $A^{+/+}$mice. ${ }^{\#} P<0.01$ vs. 2 days of reperfusion in GC- $A^{+/+}$mice. sham-operated mice; $P<0.05)$, indicating GC-A is activated during ischemia/reperfusion.

Decreased myocardial infarct size in GC-A-/- mice. The hearts of $\mathrm{GC}-A^{+/+}$and $\mathrm{GC}-A^{-/-}$mice were subjected to ischemia/reperfusion. Just before the excision, hearts were perfused with Evans blue dye, sectioned, and incubated in $1.5 \%$ TTC as described in Methods. Photographs of representative ventricular sections from wild-type and $G C-A^{-/-}$mice are shown in Figure 1a. Figure 1b illustrates a scheme showing the infarct area, AAR, and nonischemic area to assist in our understanding. The blue-stained tissue was defined as being perfused, the rest of the section was defined as AAR, and regions within the AAR that failed to exhibit brick-red staining were considered to be infarcts. AAR/LV ratios were not significantly different in the two genotypes $\left(G C-A^{+/+}, 64.5 \pm 7.2 \%\right.$; $G C-A^{-/-}, 63.2 \pm$ 4.2\%) (Figure 1c), indicating that there was no genotypedependent difference in the extent of AAR produced by complete occlusion of the LAD and indicating that ligation site is the same in both groups. On the other hand,
infarct/AAR was significantly smaller in GC- $A^{-/-}$mice after 2 days of reperfusion $\left(G C-A^{+/+}, 58.2 \pm 5.2 \%\right.$; $G C-A^{-/-}$, $44.6 \pm 3.7 \% ; P<0.05$ ) (Figure 1d). Infarct/LV was also significantly smaller in $G C-A^{-/-}$mice after 2 days of reperfu$\operatorname{sion}\left(G C-A^{+/+}, 37.5 \pm 3.4 \%\right.$; GC- $\left.A^{-/-}, 28.2 \pm 1.6 \% ; P<0.05\right)$ (Figure 1e), demonstrating that the amount of myocardial tissue salvaged during reperfusion was larger in the absence of endogenous GC-A.

Decreased PMN infiltration number in GC- $A^{-/-}$mice. One of the hallmarks of reperfusion injury is the accumulation of PMNs within the injured tissue (34). In fact, interventions aimed at inhibiting PMN accumulation have been shown to exert cardioprotective effects in various experimental models. And in the present study, comparison of Figure 2, b and d, with Figure 2, a and c, illustrates that the number of PMNs infiltrating the myocardium was indeed diminished in GC- $A^{-/-}$mice. Summarizing the counts from at least ten randomly selected microscope fields, we found that significantly fewer PMNs were present in the myocardium of $G C-A^{-/-}$

Table 1

Ventricular ANP and BNP concentrations in mice after ischemia/reperfusion

$6 \mathrm{~h}$

\begin{tabular}{|c|c|c|c|c|c|}
\hline & Control & Sham & MI & Sham & MI \\
\hline ANP (ng/g wet tissue) & $12.3 \pm 2.7$ & $16.5 \pm 0.6$ & $41.8 \pm 11.8^{\mathrm{A}}$ & $15.6 \pm 4.7$ & $30.5 \pm 2.7$ \\
\hline BNP (ng/g wet tissue) & $38.9 \pm 5.8$ & $53.3 \pm 4.8$ & $146.1 \pm 26.2^{\mathrm{B}}$ & $59.2 \pm 12.9$ & $220.3 \pm 35^{B}$ \\
\hline
\end{tabular}

$2 d$ 
a

$\begin{array}{lllll}\text { Sample } & + & - & + & + \\ \text { Probe } & + & + & - & + \\ \text { Antibody } & - & - & - & \mathrm{p} 50\end{array}$

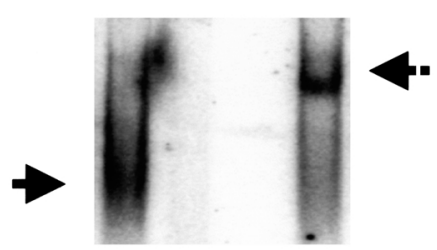

c

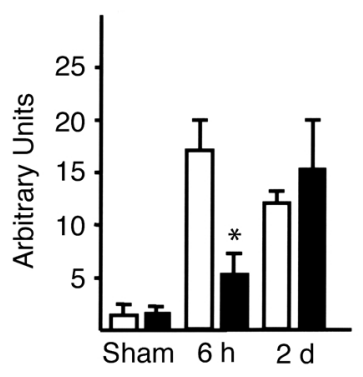

f

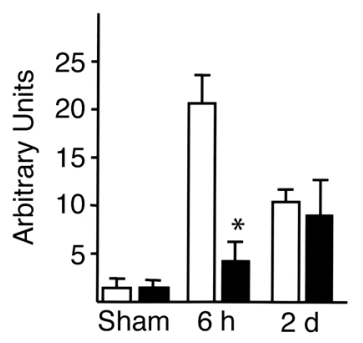

b
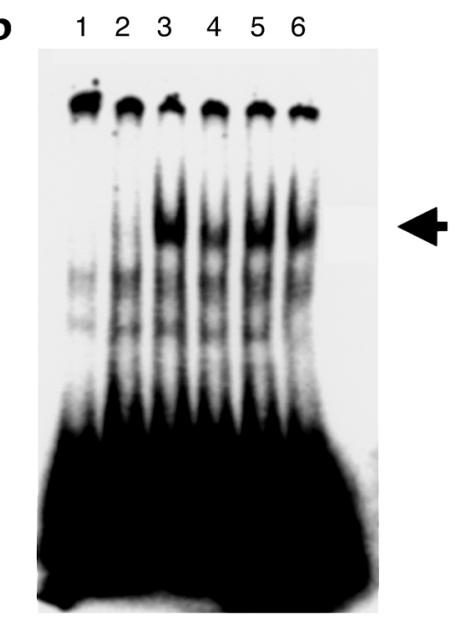

d $\begin{array}{llllll}1 & 2 & 3 & 4 & 5 & 6\end{array}$

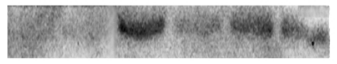

e $\quad 1 \quad 2 \quad 3 \quad 3 \quad 4 \quad 5 \quad 6$

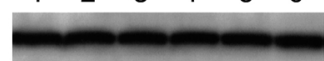

Figure 4

NF- $\kappa \mathrm{B}$ binding to DNA during myocardial ischemia/reperfusion in GC- $A^{+/+}$and GC- $A^{-/-}$mice. (a) The identity of the band obtained from a NF$\kappa \mathrm{B}$ gel shift assay was confirmed by competition and supershift analyses using a specific anti-p50 subunit $A b$ as a probe. An arrow in left side shows shifted band. An arrow with broken line shows supershifted band. (b) EMSA of NF- $\kappa B$ in GC- $A^{+/+}$ (lanes 1, 3, and 5) and GC- $A^{-/-}$(lanes 2, 4, and 6) hearts; lanes 1 and 2, sham operated; lanes 3 and 4, 30 minutes of ischemia and 6 hours of reperfusion; lanes 5 and 6, 30 minutes of ischemia and 2 days of reperfusion. (c) Semiquantitative analysis of the binding of activated NF-KB to DNA in $G C-A^{+/+}$(open bars) and GC- $A^{-/-}$mice (filled bars). (d and $\mathbf{e})$ Western blot analysis showing phosphorylated $I \kappa B \alpha(\mathbf{d})$ and total $I \kappa B \alpha$ protein expression (e) in left ventricles of GC- $A^{+/+}$(lanes 1 , 3 , and 5) and GC- $A^{-/-}$(lanes 2, 4, and 6) mice after 30 minutes of ischemia and 6 hours (lanes 3 and 4) or 2 days (lanes 5 and 6 ) of reperfusion. Lanes 1 and 2 show phosphorylated $I \kappa B \alpha(\mathbf{d})$ and total $\mid \kappa B \alpha$ protein expression (e) without ischemia/reperfusion. ( $\mathbf{f}$ and $\mathbf{g}$ ) Semiquantitative analysis of phosphorylated $I \kappa B \alpha(f)$ and total $I \kappa \mathrm{B} \alpha(\mathbf{g})$ protein expression. Phosphorylated $\mathrm{I} \mathrm{B} \alpha$ was significantly lower in GC- $A^{-/-}$mice (filled bars) than in GC- $A^{+/+}$mice (open bars) after 6 hours of reperfusion $(\mathbf{f}) .{ }^{*} P<0.01$ vs. 6 hours of reperfusion in GC- $A^{+/+}$mice. mice after both 6 hours $\left(G C-A^{+/+}, 16 \pm 6\right.$ PMNs per highpowered field; $G C-A^{-/}, 8 \pm 3$ PMNs per high-powered field; $P<0.01)$ and 2 days $\left(G C-A^{+/+}, 42 \pm 3\right.$ PMNs per high-powered field; GC- $A^{-/-}, 17 \pm 4$ PMNs per highpowered field; $P<0.01$ ) reperfusion (Figure $2 \mathrm{e}$ ).

Decreased MPO activity in GC- $A^{-/-}$mice. To further quantify the extent of PMN infiltration, we measured the activity of cardiac MPO, an enzyme specific to activated neutrophils. This method is commonly used to assess neutrophil accumulation and has been validated previously in cardiac tissue (27). When myocardial MPO activity was measured in infarcted and noninfarcted tissues after 6 hours or 2 days of reperfusion, we found that the activity time dependently increased within the infarcted areas of both $G C-A^{-/-}$and wild-type mice $\left(G C-A^{+/+}, 0.46 \pm 0.08 \mathrm{U} / 100 \mathrm{mg}\right.$ tissue; $G C-A^{-/-}$, $0.31 \pm 0.06 \mathrm{U} / 100 \mathrm{mg}$ tissue after 6 hours of reperfusion; $G C-A^{+/+}, 1.68 \pm 0.03 \mathrm{U} / 100 \mathrm{mg}$ tissue; $G C-A^{-/-}, 1.17$ $\pm 0.03 \mathrm{U} / 100 \mathrm{mg}$ tissue after 2 days of reperfusion) but that it was significantly lower in the GC-A-deficient mice at either time point (Figure $2 \mathrm{f}$ ). Within noninfarct areas, MPO activity was very low in both genotypes.

Decreased $P$-selectin expression in GC- $A^{-/-}$mice. Endothelial cell surface expression of P-selectin (CD62), an integral membrane protein rapidly translocated to the plasma membrane during exocytosis of the Weibel-Palade bodies, promotes the binding and "rolling" of neutrophils, which precedes their migration into sites of inflammation (35-41). To investigate the mechanism responsible for the reduced PMN infiltration in GC-A-deficient mice, we examined P-selectin expression after ischemia/reperfusion. Immunohistochemical analysis revealed that after 2 days of reperfusion, P-selectin was expressed in coronary microvascular endothelial cells in perinecrotic areas of both wild-type (Figure 3, a, c, and e) and GC-A $A^{-/-}$(Figure $3, \mathrm{~b}, \mathrm{~d}$, and $\mathrm{f}$ ) mice, although the latter were labeled to a lesser degree. In contrast, P-selectin expression was barely detectable in sham-operated hearts. Western blot analysis, moreover, confirmed the significant $(P<0.01)$ declines in P-selectin expression in $G C-A^{-/-}$mice after either 6 hours of reperfusion $\left(G C-A^{+/+}, 3.11 \pm 0.26\right.$ arbitrary units; $G C-A^{-/-}, 1.83 \pm 0.08$ arbitrary units; $\left.P<0.01\right)$ or 2 days of reperfusion $\left(G C-A^{+/+}, 5.65 \pm 0.40\right.$ arbitrary units; $G C-A^{-/-}, 3.64 \pm 0.53$ arbitrary units; $P<0.01$ ) (Figures 3 , g and $h$ ). Thus, the reduced $P M N$ accumulation during ischemia/reperfusion in GC-A-deficient mice is likely due, at least in part, to suppressed expression of Pselectin in coronary endothelial cells. 


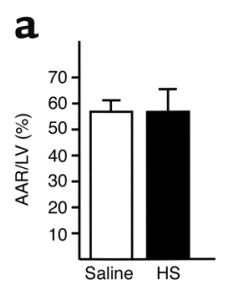

b

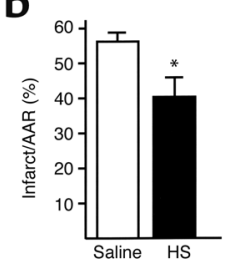

C

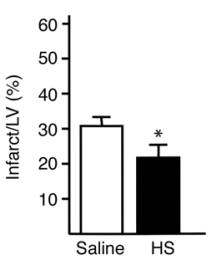

f d

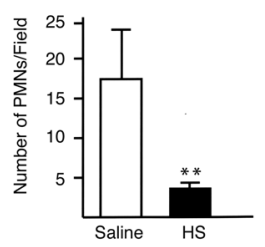

g

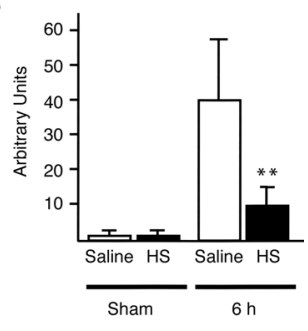

\section{Figure 5}

Myocardial infarct size, PMN infiltration, MPO activity, and P-selectin expression in HStreated mice after 30 minutes of ischemia and 6 hours of reperfusion. (a) AAR/LV was not significantly different in the two groups. (b) Infarct/AAR was significantly smaller in HS-treated mice (filled bars) than in saline-treated mice (saline; open bars) after 2 days of reperfusion. ${ }^{*} P<0.05$ vs. saline group. (c) Infarct/LV was significantly decreased in HS-treated mice compared with that in saline-treated mice. ${ }^{*} P<0.05$ vs. saline group. Numbers of infiltrating PMNs per field (d) and MPO activity (e) were both significantly lower in HS-treated mice. ${ }^{*} P<0.01$ vs. saline group. (f) Western blot analysis of P-selectin expression following ischemia/reperfusion in mice pretreated with saline (lane 3) or HS (lane 4); lanes 1 and 2, P-selectin in sham-operated mice treated with saline and HS, respectively. (g) Semiquantitative analysis of P-selectin expression in HStreated mice. Little P-selectin expression was seen in sham-operated mice. P-selectin expression was increased in all mice subjected to ischemia/reperfusion, although significantly $(P<0.01)$ less so in HS-treated mice (filled bars) than in saline-treated mice (open bars). ${ }^{*} P<0.01$ vs. saline group.

Reduced NF- $\mathrm{KB}$ activity in $\mathrm{GC}-\mathrm{A}^{-/-}$mice. NF- $\mathrm{KB}$ is a transcription factor that, by regulating the gene expression of multiple cytokines, chemokines, cell adhesion molecules, growth factors, and immunoreceptors, plays a critical role in immune and inflammatory reactions $(42,43)$.

The P-selectin gene, which contains a functional $\mathrm{NF}-\mathrm{KB}$-binding site, is required for its induction in endothelial cells (44). We therefore assessed NF- $\mathrm{KB}$ activation using EMSA with a NF- $\kappa \mathrm{B}$ binding site-specific probe and nuclear proteins isolated from myocardial tissues of $G C-A^{-/-}$and $G C-A^{+/+}$mice. No activation of NF- $\kappa B$ was detected in sham-operated mice of either genotype (Figure 4b, lanes 1 and 2, respectively). In contrast, incubation with nuclear extracts from wild-type mice after 6 hours of reperfusion yielded a clearly detectable band (Figure 4b, lane 3), the identity of which was confirmed by competition and supershift analyses with a specific $A b$ against the NF- $\kappa B$ p50 subunit (Figure 4a). NF- $\kappa B$ activity was increased after 6 hours of reperfusion in wild-type mice (Figure 4b, lane 3 ) and maintained until 2 days after reperfusion (Figure $4 \mathrm{~b}$, lane 5). In contrast, NF- $\mathrm{KB}$ activation was not detectable in $\mathrm{GC}-A^{-/-}$mice after 6 hours of reperfusion (Figure $4 \mathrm{~b}$, lane 4 ) but elevated to the same level as $\mathrm{GC}-\mathrm{A}^{+/+}$mice after 2 days of reperfusion (Figure

4b, lane 6). Densitometric scanning of the shifted bands revealed a 70\% decline in NF- $\kappa B$ activity in GC- $A^{-/-}$after 6 hours of reperfusion $\left(G C-A^{+/+}, 16.52 \pm 1.87\right.$ arbitrary units; GC- $A^{-/-}, 4.86 \pm 1.56$ arbitrary units) (Figure 4c), which implies that GC-A might play a distinctive role in modulating ischemia/reperfusion injuries through inhibition of NF- $\mathrm{KB}$ activation. I $\mathrm{B} \alpha$ was phosphorylated in $G C-A^{+/+}$mice, whereas it is not phosphorylated in GC- $A^{-/-}$mice after 6 hours of reperfusion. Phosphorylation of IKB $\alpha$ in GC- $A^{+/+}$mice and GC- $A^{-/-}$mice after 2 days of reperfusion were upregulated to the same level. However, there was no significant change in I $\kappa \mathrm{B} \alpha$ protein level in GC- $A^{-/-}$mice and GC- $A^{+/+}$mice after both 6 hours and 2 days of reperfusion (Figure 4, d-g).

Decreased myocardial infarct size, $P M N$ infiltration, and P-selectin expression in mice treated with HS. To rule out that these effects were restricted within $G C-A^{-/-}$ mice, we next examined the effects of HS. Blockade of GC-A by intravenous injection of HS $(3 \mathrm{mg} / \mathrm{kg})$ was initially confirmed by the evoked decline in basal plasma cGMP levels $(11.5 \pm 1.7$ $\mathrm{pmol} / \mathrm{ml}$ in saline vs. $7.4 \pm 0.6 \mathrm{pmol} / \mathrm{ml}$ in HS; $P<0.05)$. Whereas AAR/LV in both groups did not change (saline, 57.9 $\pm 3.0 \%$; HS, $57.3 \pm 7.2 \%$ ) (Figure $5 \mathrm{a}$ ) after 2 days of reperfusion, injection of HS 30 minutes before coronary occlusion significantly reduced infarct/AAR ratio (saline, $56.5 \pm 2.3 \%$; HS, $38.7 \pm 3.3 \% ; P<0.05$ ) (Figure $5 \mathrm{~b}$ ) and infarct/LV ratio (saline, $32.7 \pm 2.1 \%$; HS, $22.2 \pm 2.5 \%$; $P<0.05$ ) (Figure $5 \mathrm{c}$ ), decreased the number of infiltrating PMNs after 2 days of reperfusion (saline, $17 \pm 7$ PMNs per high-powered field; HS, $4 \pm 1$ PMNs per high-powered field; $P<0.01$ ) (Figure 5d), and decreased the MPO activity after 6 hours of reperfusion (saline, $0.42 \pm 0.16 \mathrm{U} / 100 \mathrm{mg}$ tissue; HS, $0.12 \pm 0.08 \mathrm{U} / 100 \mathrm{mg}$ tissue; $P<0.01$ ) (Figure $5 \mathrm{e}$ ). Western blot analysis revealed that HS reduced the level of cardiac P-selectin expression seen after 6 hours of reperfusion (saline, $39.6 \pm 10.4$ arbitrary unit; HS, $8.9 \pm 2.8$ arbitrary unit; $P<0.01$ ) (Figure 5 , $\mathrm{f}$ and $\mathrm{g}$ ), and there was a corresponding decline in the immunolabeling of $\mathrm{P}$ selectin in coronary endothelial cells (data not shown). These findings further support the notion that blockade of endogenous natriuretic peptides decreases myocardial PMN infiltration after ischemia/reperfusion by inhibiting expression of P-selectin on endothelial cells.

Induction of P-selectin expression in HUVECs by ANP. The aforementioned findings led us to hypothesize that ANP directly influences endothelial P-selectin expression during ischemia/reperfusion. To test this hypothesis, we assessed the effect of ANP on P-selectin expression in 


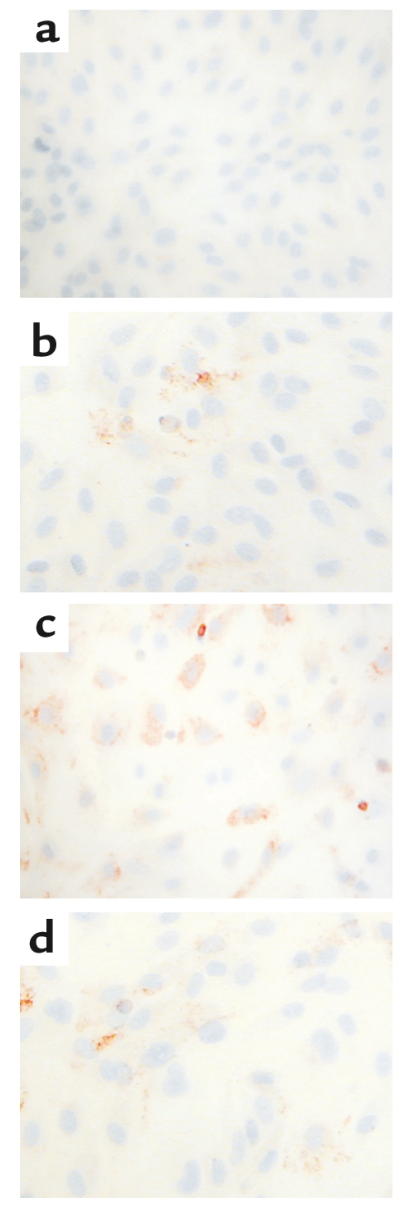

e

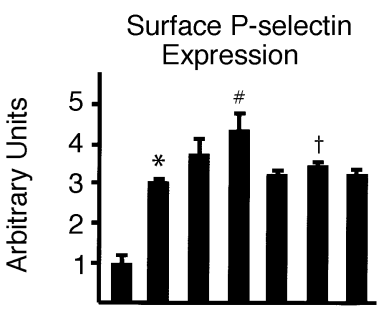

$\mathrm{H}_{2} \mathrm{O}_{2}-++++++$ ANP (M) - - $10^{-8} 10^{-6} 10^{-8} 10^{-6}-$ HS-142-1 - - - + + +

f

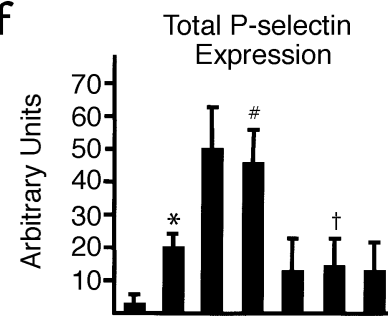

$\mathrm{H}_{2} \mathrm{O}_{2}-++++++$ ANP (M) - - $10^{-8} 10^{-6} 10^{-8} 10^{-6}-$ HS-142-1 - - - + + +

\section{Figure 6}

(a-d) Immunolabeling of P-selectin in HUVECs. (a) Unstimulated cells. (b) Cells treated with $\mathrm{H}_{2} \mathrm{O}_{2}(100 \mu \mathrm{M})$. (c) Cells treated with ANP (1 $\mu \mathrm{M})$ in the presence of $\mathrm{H}_{2} \mathrm{O}_{2}(100 \mu \mathrm{M})$. (d) Cells treated with ANP (1 $\mu \mathrm{M})$ in the presence of $\mathrm{HS}(100 \mu \mathrm{g} / \mathrm{ml})$ and $\mathrm{H}_{2} \mathrm{O}_{2}(100 \mu \mathrm{M})$. (e and $\left.\mathbf{f}\right)$ Cell surface $(\mathbf{e})$ and total $(\mathbf{f})$ expression of $\mathrm{P}$-selectin was increased by exposure to $100 \mu \mathrm{M} \mathrm{H}_{2} \mathrm{O}_{2}$ and was increased further by exposure to $\mathrm{H}_{2} \mathrm{O}_{2}$ plus ANP $\left(P<0.05\right.$ vs. $\mathrm{H}_{2} \mathrm{O}_{2}$ alone $)$. The effect of ANP was abolished by HS. ${ }^{*} P<0.01$ vs. saline-treated group. ${ }^{\#} P<0.01$ vs. $\mathrm{H}_{2} \mathrm{O}_{2}$ treated group. $P<0.01$ vs. $\mathrm{H}_{2} \mathrm{O}_{2}$ - and ANP-treated group.

cultured HUVECs in the presence or absence of $\mathrm{H}_{2} \mathrm{O}_{2}$, a toxic by-product of respiration. Although we found only minimal immunolabeling of P-selectin (stained red) under basal conditions (Figure 6a), several cells were labeled in the presence of $100 \mu \mathrm{M} \mathrm{H}_{2} \mathrm{O}_{2}$ (Figure 6b), indicating that exposure to $\mathrm{H}_{2} \mathrm{O}_{2}$ induced expression of $\mathrm{P}$ selectin. When incubated with $\mathrm{H}_{2} \mathrm{O}_{2}$ plus $10^{-6} \mathrm{M}$ ANP, more cells were labeled and to a stronger degree than with $\mathrm{H}_{2} \mathrm{O}_{2}$ alone (Figure $6 \mathrm{c}$ ), while exposure to $\mathrm{H}_{2} \mathrm{O}_{2}$, $\mathrm{ANP}$, and $100 \mu \mathrm{g} / \mathrm{ml} \mathrm{HS}$ resulted in cells being labeled to the same degree seen with $\mathrm{H}_{2} \mathrm{O}_{2}$ alone (Figure 6d).

Using a specific ELISA, we examined translocation of P-selectin to cell surface and total P-selectin expression of HUVECs. Treating cells for 1 hour with ANP alone dose dependently increased cell surface expression of P-selectin (saline, $1 \pm 0.13$; ANP $10^{-8} \mathrm{M}, 2.34 \pm 0.41$; ANP $10^{-6} \mathrm{M}, 3.64 \pm 0.23$ arbitrary units) (data not shown), and $100 \mu \mathrm{M} \mathrm{H}_{2} \mathrm{O}_{2}$ alone for 1 hour increased cell surface P-selectin expression, as well. Cell surface expression of P-selectin in the presence of ANP was further increased by addition of $100 \mu \mathrm{M} \mathrm{H}_{2} \mathrm{O}_{2}$, which was suppressed by pretreatment with $100 \mu \mathrm{g} / \mathrm{ml}$ HS (Figure 6e). Incubating cells with ANP for 6 hours in the presence of $100 \mu \mathrm{M} \mathrm{H}_{2} \mathrm{O}_{2}$ increased total expression of Pselectin, effects of which again were abolished by prior addition of HS (Figure 6f).

Finally, cell viability assays, in which mitochondrial respiration was assessed as a function of the mitochondriadependent reduction of WST-8 to formazan, revealed that $\mathrm{H}_{2} \mathrm{O}_{2}, \mathrm{ANP}$, and $\mathrm{HS}$, either alone or in combination, had no effect on endothelial cell viability (data not shown). Thus, ANP appears to directly increase both cell surface and total expression of P-selectin protein in endothelial cells under oxidative stress.

$\mathrm{NF}-\mathrm{KB}$ activation by ANP and/or $\mathrm{H}_{2} \mathrm{O}_{2}$ in HUVECs. We showed that NF- $\kappa \mathrm{B}$ was activated in an ischemia/reperfusion model of wild-type mice, while it was not acti-

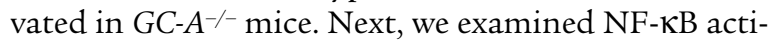
vation in HUVECs, which were treated with ANP in the presence of $\mathrm{H}_{2} \mathrm{O}_{2}$. As shown in Figure 7, a and b, $10^{-6} \mathrm{M}$ ANP alone did not activate NF- $\kappa B$ in HUVECs. Modest activation of NF- $\kappa \mathrm{B}$ was observed in $\mathrm{H}_{2} \mathrm{O}_{2}$-treated HUVECs in a good agreement with the previous report (45). Surprisingly, ANP greatly augmented $\mathrm{H}_{2} \mathrm{O}_{2}$ induced NF- $\mathrm{KB}$ activation in HUVECs. These effects were abolished with HS (Figure 7, a and b). These results strongly suggest that, under oxidative condition as in ischemia/reperfusion, ANP could activate NF- $\mathrm{KB}$ in vascular endothelial cells. To further examine the mechanism for NF- $\mathrm{KB}$ activation, we performed Western blot analysis using specific $\mathrm{Ab}$ for phosphorylated

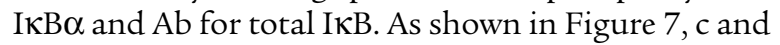
e, $10^{-6} \mathrm{M}$ ANP alone did not phosphorylate I $\mathrm{B} \mathrm{B} \alpha$, but $\mathrm{H}_{2} \mathrm{O}_{2}$ phosphorylated it. When ANP was added in combination with $\mathrm{H}_{2} \mathrm{O}_{2}$, I $\kappa \mathrm{B} \alpha$ was phosphorylated more compared with that by $\mathrm{H}_{2} \mathrm{O}_{2}$ alone. However, incubation of cells with ANP in the presence of $\mathrm{H}_{2} \mathrm{O}_{2}$ did not affect degradation of I $\mathrm{K} \alpha \alpha$ (Figure 7, $\mathrm{d}$ and $\mathrm{f}$ ).

Incubation with ANP did not affect reactive oxygen species production in HUVECs. To investigate if ANP directly produces reactive oxygen species, we examined intracellular peroxides in HUVECs treated or not treated with ANP. The flow cytometric data shows the occurrence of oxidative stress in HUVECs exposed to hydrogen peroxide. In contrast, exposure of cells to $10^{-6} \mathrm{M}$ ANP did not affect carboxy- $\mathrm{H}_{2}$ DCFDA oxidation, indicating that ANP does not directly induce oxidative stress in endothelial cells (data not shown).

\section{Discussion}

In the present study, we investigated the significance of the natriuretic peptide receptor, GC-A, during myocardial ischemia/reperfusion using genetically engineered GC-A-null mice. Surprisingly, myocardial infarct size after 2 days of reperfusion was approximately $20 \%$ smaller in GC-A-deficient mice than in wild-type mice. 


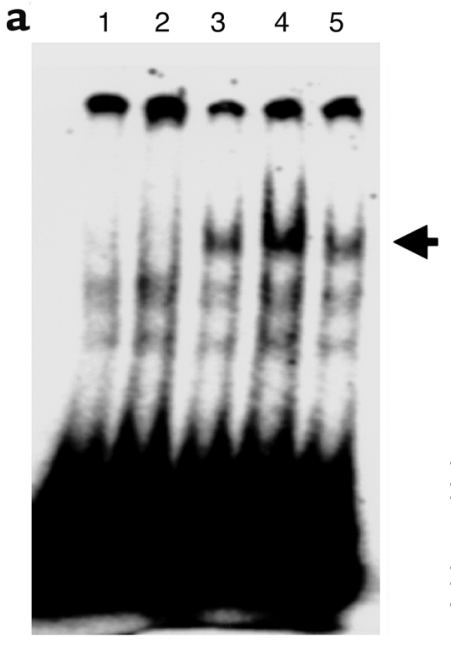

b

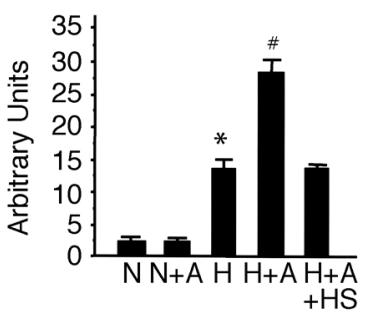

C

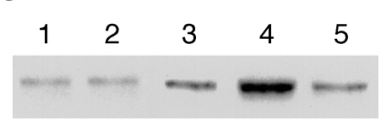

e

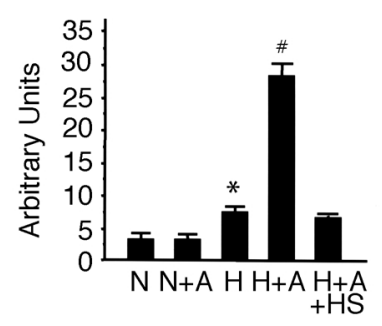

d

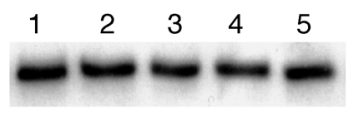

f

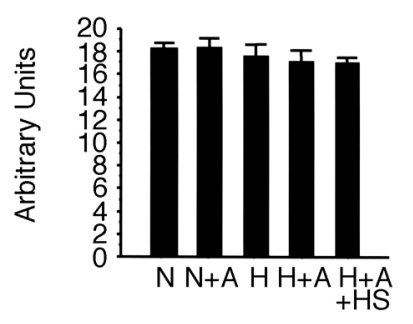

Infarct size was also smaller in wild-type mice pretreated with HS, a nonpeptide GC-A antagonist. This reduction in infarct size was accompanied by corresponding declines in PMN infiltration, coronary endothelial cell expression of P-selectin, and activation of NF- $\mathrm{KB}$. In addition, ANP directly induced upregulation of Pselectin expression in the presence or absence of $\mathrm{H}_{2} \mathrm{O}_{2}$, and ANP modulated $\mathrm{H}_{2} \mathrm{O}_{2}$-induced NF- $\mathrm{KB}$ activation in endothelial cells, the effects of which were abolished by pretreating cells with HS.

Recent studies have shown that myocardial ischemia/ reperfusion injury could be suppressed by preventing PMN accumulation by inhibition of P-selectin, L-selectin, ICAM-1, or CD18, which are leukocyte adhesion receptors or cell adhesion molecules. For example, the sizes of myocardial infarcts elicited by ischemia/reperfusion were diminished in P-selectin-deficient, ICAM-1-deficient, or CD18-deficient mice $(46,47)$. In addition, ischemia/ reperfusion-induced PMN infiltration and myocardial infarct size were both diminished in dogs treated with a monoclonal anti-P-selectin $\mathrm{Ab}(48)$, and myocardial ischemia/reperfusion injuries were reduced by monoclonal $\mathrm{Ab}$ 's directed against leukocyte adhesion receptor or cell adhesion molecules (49-51). It thus appears that suppression of cell adhesion molecules or leukocyte

\section{Figure 7}

NF- $\kappa B$ activation, I $\mid \kappa B \alpha$ phosphorylation, and $I \kappa B \alpha$ degradation in ANP- and/or $\mathrm{H}_{2} \mathrm{O}_{2}$-treated HUVECs. (a) EMSA of NF- $\mathrm{KB}$ in control cells (lane 1 ), ANP-treated cells (lane 2), $\mathrm{H}_{2} \mathrm{O}_{2}$-treated cells (lane 3 ), ANP with $\mathrm{H}_{2} \mathrm{O}_{2}$-treated cells (lane 4), ANP and $\mathrm{HS}$ with $\mathrm{H}_{2} \mathrm{O}_{2}$-treated cells (lane 5). An arrow in right side indicates shifted band. (b) Semiquantitative analysis of the binding of activated NF-KB to DNA in HUVECs. Level of NF- $\kappa B$ activation was significantly higher in $\mathrm{H}_{2} \mathrm{O}_{2}$-treated cells $(\mathrm{H})$ compared with control cells $(\mathrm{N})$ and was further increased in ANP with $\mathrm{H}_{2} \mathrm{O}_{2}$-treated cells $(\mathrm{H}+\mathrm{A})$ compared with $\mathrm{H}_{2} \mathrm{O}_{2}$-treated cells. This effect was abolished by treatment with $\mathrm{HS}$ $(\mathrm{H}+\mathrm{A}+\mathrm{HS}) .{ }^{*} P<0.01$ vs. control cells. ${ }^{\#} P<0.01$ vs. $\mathrm{H}_{2} \mathrm{O}_{2}$-treated cells. Western blot analysis of I $\mathrm{KB} \alpha$ phosphorylation (c) and total I $\mathrm{K} \alpha \alpha$ protein expression (d) in HUVECs. Lane 1, control cells; lane 2, ANP-treated cells; lane 3, $\mathrm{H}_{2} \mathrm{O}_{2}$-treated cells; lane 4, $\mathrm{H}_{2} \mathrm{O}_{2}$ with ANPtreated cells; lane $5, \mathrm{H}_{2} \mathrm{O}_{2}$ with ANP- and HS-treated cells. I $\mathrm{KB} \alpha$ was not phosphorylated by ANP alone, but by $\mathrm{H}_{2} \mathrm{O}_{2}$, and IKB $\alpha$ phosphorylation was further strengthened by ANP with $\mathrm{H}_{2} \mathrm{O}_{2}$. This effect was abolished by $\mathrm{HS}(\mathbf{c})$. I $\mathrm{KB} \alpha$ protein expression did not change among all groups (d). Densitometric scanning of I $\mathrm{K} B \alpha$ phosphorylation (e) and $\mathrm{I} \mathrm{\kappa B} \alpha$ protein expression (f). Phosphorylation of $\mathrm{I} \mathrm{KB} \alpha$ in $\mathrm{H}_{2} \mathrm{O}_{2}$-treated cells is significantly increased compared with control cells. It further increased significantly in $\mathrm{H}_{2} \mathrm{O}_{2}$ with ANP-treated cells compared with $\mathrm{H}_{2} \mathrm{O}_{2}$-treated cells (e). There is no significant change in $\mathrm{I} \mathrm{KB} \alpha$ protein expression among all groups $(\mathbf{f}) .{ }^{*} P<0.05$ vs. control cells. ${ }^{\#} P<0.01$ vs. $\mathrm{H}_{2} \mathrm{O}_{2}$-treated cells.

adhesion receptors reduces ischemia/reperfusion injury and infarct size during the acute phase of myocardial ischemia/reperfusion. These reports are consistent with our present finding that GC-A inhibition and reduced expression of P-selectin were accompanied by decreases in myocardial PMN infiltration and infarct size.

To investigate the mechanism responsible for the attenuated expression of P-selectin in GC-A-deficient mice, $\mathrm{NF}-\mathrm{\kappa B}$ activation, which is known to promote P-selectin gene expression (52), was assessed. In endothelial cells, NF- $\kappa B$ exists as a heterodimer made up of subunits designated p50 and p65 and is localized to the cytoplasm in the inactive form. Once activated by phosphorylation of $\mathrm{I} \kappa \mathrm{B}$, an inhibitory protein, NF- $\mathrm{KB}$ is translocated to the nucleus, where it initiates transcription of a variety proinflammatory genes, including P-selectin (53). We found that NF- $\mathrm{KB}$ activation was suppressed after 6 hours of reperfusion in GC-A-deficient mice, suggesting that decreases in P-selectin expression, in the number of infiltrating PMNs, and in myocardial infarct size could be at least partly due to the inhibition of ischemia/reperfusion-induced NF- $\mathrm{KB}$ activation in GC-A-deficient hearts. As shown in Figure 4, b and c, NF- $\mathrm{KB}$ activation in $G C-A^{-/-}$mice was elevated to the same level as GC- $A^{+/+}$ mice after 2 days of reperfusion. Although the precise reason for the absence of difference in NF- $\mathrm{kB}$ activation after 2 days of reperfusion was not clear, one possible explanation is that there are many other mechanisms involved in NF- $\mathrm{KB}$ activation in the late phase of ischemia/reperfusion. In 2 days of reperfusion, NF- $\kappa B$ might be activated by other cytokines, for example, TNF- $\alpha$. Our unpublished observations suggest that TNF- $\alpha$ mRNA level peaks at 2-3 days after myocardial infarction in mice. 
We found previously that GC-A-deficient mice, which are derived from the C57BL/6 and SVJ 129 strains, are hypertensive and exhibit marked ventricular hypertrophy (26). Even though these mice were backcrossed with C57BL/6 mice for at least five generations and comparisons were made among littermates, it was still possible that the observed differences in infarct size might have been due to differences in the hemodynamics or genetic backgrounds of the mice. To rule out that possibility, we blocked endogenous GC-A pharmacologically using HS at a dosage that did not affect systemic blood pressure (data not shown). Pretreatment with HS reduced myocardial infarct size and coronary endothelial P-selectin expression, confirming the role played by endogenous GC-A during myocardial ischemia/reperfusion in wild-type mice.

To further investigate whether ANP directly affects Pselectin expression, we examined P-selectin expression in cultured HUVECs, where GC-A is abundantly expressed. Treating the cells with ANP increased both cell surface expression (Figure 6e) and total expression of P-selectin protein (Figure 6f). Because ischemia/ reperfusion injury is known to correlate with oxidative stress, we exposed HUVECs to $\mathrm{H}_{2} \mathrm{O}_{2}$ and found that it, too, increased cell surface (Figure 6e) and total (Figure 6f) expression of $\mathrm{P}$-selectin, while combined exposure to ANP and $\mathrm{H}_{2} \mathrm{O}_{2}$ yielded even larger increases, which were blocked by pretreatment with HS.

It is very important to examine how ANP or BNP activates NF- $\mathrm{KB}$ since little is known regarding cross-talk between the natriuretic peptide pathway and the NF- $\kappa \mathrm{B}$ pathway. However, Kalra et al. recently reported that cyclic GMP-dependent kinase directly interacts with and phosphorylates $I \kappa \mathrm{B} \alpha$, which leads to the activation of NF- $\mathrm{KB}$ in feline cardiomyocytes (54). Considering the findings, we examined phosphorylation and degradation of I $\kappa \mathrm{B} \alpha$ in $\mathrm{ANP} / \mathrm{H}_{2} \mathrm{O}_{2}$-treated HUVECs. Incubation of HUVEC with ANP for 1 hour alone did not either phosphorylate $\mathrm{I} \kappa \mathrm{B} \alpha$ or activate NF- $\kappa \mathrm{B}$. ANP further augmented $\mathrm{H}_{2} \mathrm{O}_{2}$-induced phosphorylation and NF- $\kappa \mathrm{B}$ activation. Incubation of cells with $\mathrm{H}_{2} \mathrm{O}_{2}$ alone did not affect degradation of $I \kappa B \alpha$. ANP in the presence of $\mathrm{H}_{2} \mathrm{O}_{2}$ also did not affect I $\kappa \mathrm{B} \alpha$ degradation. These data agree well with the previous report (45). These results provide the evidence that ANP modulates $\mathrm{NF}-\kappa \mathrm{B}$ activation in the presence of oxidative stress through I $\mathrm{B} \alpha \alpha$ phosphorylation without degradation. As the synthesis and secretion of BNP are markedly augmented after acute myocardial infarction (22), it is likely that endogenous natriuretic peptides upregulate Pselectin expression during ischemia/reperfusion. Although, to our knowledge, there have been no reports on the effect of natriuretic peptides on the expression of endothelial adhesion molecules, Steven et al. (55) showed P-selectin expression to be upregulated and infarct size to be larger in eNOS-deficient mice. It is intriguing to us that GC-A- and eNOS-knockout mice show opposite tendencies with respect to P-selectin expression, even though both natriuretic peptides and NO transduce their signals by elevating the level of cGMP. The reason for this discrepancy is currently unknown, and it would be interesting to examine the NO pathway in $G C-A^{-/-}$mice.

In the present study, it is indicated that the increase in natriuretic peptide levels might play an important role in regulating inflammatory responses after cardiac ischemia reperfusion. Furthermore, our finding that GC-A inhibition during the acute phase has a beneficial effect on myocardial reperfusion injury raises the possibility of future clinical application. However, we must clarify the effect of suppressing inflammatory response in the infarct area on healing processes and the effect of remodeling during the chronic phase in noninfarct lesions. Therefore, additional study will be necessary to determine the clinical applicability of GC-A inhibition and the most appropriate timing and extent to which GC-A should be inhibited during acute myocardial ischemia and reperfusion.

At present, ANP has been used clinically to treat patients with acute heart failure, including patients with AMI who have undergone acute reperfusion therapy. When ANP is infused to patients at a rate of 0.1 $\mu \mathrm{g} / \mathrm{kg} / \mathrm{min}$, the plasma concentration of ANP reached approximately $3 \mathrm{ng} / \mathrm{ml}(1 \mathrm{nM})$. In contrast, the ventricular concentration of ANP in the normal ventricle is about $17.5 \mathrm{ng} / \mathrm{g}(56)$, which corresponds to about $6 \mathrm{nM}$, and could be increased after ischemia/reperfusion, as is the case in mice (Table 1). Thus, ventricular ANP concentration is several times higher than plasma concentration, even in ANP-treated patients. Therefore, it is unlikely that ANP infusion augments to a greater extent cardiac P-selectin expression or PMN infiltration. On the other hand, ANP infusion improves preload and afterload through diuretic, natriuretic, and vasodilating activities of ANP. Further studies are necessary to evaluate whether ANP infusion before or just after reperfusion of coronary artery in AMI is useful or harmful.

In conclusion, inhibition of the natriuretic peptide

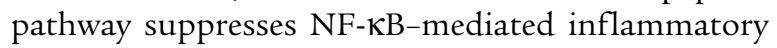
processes during acute myocardial ischemia/reperfusion, and, as a result, reduces myocardial infarct size. The present study provides a new insight into the role of natriuretic peptide/GC-A pathway in myocardial ischemia/reperfusion.

\section{Acknowledgments}

This work was supported in part by research grants from the Japanese Ministry of Education, Science and Culture; the Japanese Ministry of Health and Welfare; and the Japanese Society for the Promotion of Science Research for the Future program (JSPS-RFTF96I00204 and JSPS-RFTF98L00801). Excellent secretarial work by T. Okumura, C. Ohta, and M. Mukai are also acknowledged. We thank M. Inoue for her technical help.

\footnotetext{
1. Stampfer, M.J., Goldhaber, S.Z., Yusuf, S., Peto, R., and Hennekens, C.H 1982. Effect of intravenous streptokinase on acute myocardial infarction: pooled results from randomized trials. N. Engl. J. Med. 307:1180-1182.

2. Stone, G.W., Brodie, B.R., Griffin, J.J., Morice, M.C., and Constantini, C. 1998. Prospective, multicenter study of the safety and feasibility of pri-
} 
mary stenting in acute myocardial infarction: in-hospital and 30-day results of the PAMI stent pilot trial. J. Am. Coll. Cardiol. 31:23-30.

3. Zahn, R., Koch, A., Rustige, J., Schiele, R., and Wirtzfeld, A. 1997. Primary angioplasty versus thrombolysis in the treatment of acute myocardial infarction. Am. J. Cardiol. 79:264-269.

4. 1997. A comparison of reteplase with alteplase for acute myocardial infarction. The Global Use of Strategies to Open Occluded Coronary Arteries (GUSTO III) Investigators. N. Engl. J. Med. 337:1118-1123.

5. Braun, E. 1985. Myocardial reperfusion: a double-edged sword? J. Clin. Invest. 76:1713-1719.

6. Lucchesi, B.R. 1990. Modulation of leukocyte-mediated myocardial reperfusion injury. Annu. Rev. Physiol. 52:561-576.

7. Muller, D.W., et al. 1990. Relationship between antecedent angina pectoris and short-term prognosis after thrombolytic therapy for acute myocardial infarction. Am. Heart. J. 119:224-231.

8. McCord, J.M. 1987. Oxygen-derived radicals: a link between reperfusion injury and inflammation. Fed. Proc. 46:2402-2406.

9. Gurevitch, J., et al. 1996. Tumor necrosis factor-alpha is released from the isolated heart undergoing ischemia and reperfusion. J. Am. Coll. Cardiol. 28:247-252.

10. Ikeda, U., Ikeda, M., Kano, S., and Shimada, K. 1994. Neutrophil adherence to rat cardiac myocyte by proinflammatory cytokines. J. Cardiovasc. Pharmacol. 23:647-652.

11. Mullane, K. 1991. Neutrophil and endothelial changes in reperfusion injury. Trends Cardiovasc. Med. 1:282-289.

12. Sheridan, FM., Dauber, I.M., McMurtry, I.F., Lesnefsky, E.J., and Horwitz, L.D. 1991. Role of leukocytes in coronary vascular endothelial injury due to ischemia and reperfusion. Circ. Res. 69:1566-1574.

13. Entman, M.L., et al. 1991. Inflammation in the course of early myocardial ischemia. FASEB J. 5:2529-2537.

14. Lucchesi, B.R. 1991. Modulation of leukocyte-mediated myocardial reperfusion injury. Annu. Rev. Physiol. 84:400-411.

15. Koller, K.J. 1991. Selective activation of B natriuretic peptide receptor by C-type natriuretic peptide. Science. 252:120-123.

16. Tan, A.C., et al. 1989. Atrial natriuretic peptide after myocardial infarction. Am. Heart. J. 118:490-494.

17. Jougasaki, M., Yasue, H., Mukoyama, M., Nakao, K., and Takahashi, K. 1990. Appearance of atrial natriuretic peptide in the ventricles in patients with myocardial infarction. Am. Heart. J. 119:92-96.

18. Mukoyama, M., et al. 1991. Augmented secretion of brain natriuretic peptide in acute myocardial infarction. Biochem. Biophys. Res. Commun. 180:431-436.

19. Morita, E., et al. 1993. Increased plasma levels of brain natriuretic peptide in patients with acute myocardial infarction. Circulation. 88:82-91.

20. Arakawa, N., Nakamura, M., Aoki, H., and Hiramori, K. 1994. Relationship between plasma level of brain natriuretic peptide and myocardial infarct size. Cardiology. 85:334-340.

21. Kettunen, R.V., Leppäluoto, J., Jounela, A., and Vuolteenaho, O. 1994 Plasma N-terminal atrial natriuretic peptide in acute myocardial infarction. Am. Heart. J. 127:1449-1455.

22. Hama, N., et al. 1995. Rapid ventricular induction of brain natriuretic peptide gene expression in experimental acute myocardial infarction. Circulation. 92:1558-1564.

23. Lin, X., Hanze, J., Heese, F., Sodmann, R., and Lang, R.E. 1995. Gene expression of natriuretic peptide receptors in myocardial cells. Circ. Res. 77:750-758

24. Nunez, D.J., Dickson, M.C., and Brown, M.J. 1992. Natriuretic peptide receptor mRNAs in the rat and human heart. J. Clin. Invest. 90:1966-1971.

25. Hirata, Y., et al. 1993. Role of endogenous atrial natriuretic peptide in DOCA-salt hypertensive rats. Effects of a novel nonpeptide antagonist for atrial natriuretic peptide receptor. Circulation. 87:554-561.

26. Lopez, M.J., et al. 1995. Salt-resistant hypertension in mice lacking the guanylyl cyclase-A receptor for atrial natriuretic peptide. Nature. 378:65-68.

27. Bradley, P.P., Priebat, D.A., Christensen, R.D., and Rothstein, G. 1982 Measurement of cutaneous inflammation: estimation of neutrophil content with an enzyme marker. J. Invest. Dermatol. 78:206-209.

28. Dignam, J.D., Lebovitz, R.M., and Roeder, R.G. 1983. Accurate transcription initiation by RNA polymerase 2 in a soluble extract from isolated mammalian nuclei. Nucleic Acids Res. 11:1475-1489.

29. Essani, N.A., McGuire, G.M., and Manning, A.M. 1996. Jaeschke H endotoxin-induced activation of the nuclear transcription factor NF-kappaB in hepatocytes, Kupffer cells and endothelial cells in vivo. J. Immunol. 156:2956-2963

30. Nakao, K., Ogawa, Y., Suga, S., and Imura, H. 1992. Molecular biology and biochemistry of the natriuretic peptide system. I. Natriuretic pep- tides. J. Hypertens. 10:907-912.

31. Lecoeur, H., Ledru, E., and Gougeon, M.L. 1998. A cytofluorometric method for the simultaneous detection of both intracellular and surface antigens of apoptotic peripheral lymphocytes. J. Immunol. Methods. 217:11-26.

32. Hosaka, Y., Yanase, H., and Iwanaga, T. 1998. Morphological analysis of olfactory receptor cells using whole-mount preparations of the rat nasal mucosa. J. Vet. Med. Sci. 60:897-904.

33. Bass, D.A., et al. 1983. Flow cytometric studies of oxidative product formation by neutrophils: a graded response to membrane stimulation. $J$. Immunol. 130:1910-1917.

34. Lucchesi, B.R. 1990. Modulation of leukocyte-mediated myocardial reperfusion injury. Annu. Rev. Physiol. 52:561-576.

35. Lawrence, M.B., and Springer, T.A. 1991. Leukocytes roll on a selectin at physiologic flow rates: distinction from and prerequisite for adhesion through integrins. Cell. 65:859-873.

36. Geng, J.G., et al. 1990. Rapid neutrophil adhesion to activated endothelium mediated by GMP-140. Nature. 343:757-760.

37. Palluy, O., Morliere, L., Gris, J.C., Bonne, C., and Modat, G. 1992. Hypoxia/reoxygenation stimulates endothelium to promote neutrophil adhesion. Free Radic. Biol. Med. 13:21-30.

38. Davenpeck, K.L., Gauthier, T.W., Albertine, K.H., and Lefer, A.M. 1994. Role of P-selectin in microvascular leukocyte-endothelial interaction in splanchnic ischemia-reperfusion. Am. J. Physiol. 267:H622-H630.

39. Jerome, S.N., Dore, M., Paulson, J.C., Smith, C.W., and Korthuis, R.J. 1994. P-selectin and ICAM-1-dependent adherence reactions: role in the genesis of postischemic no-reflow. Am. J. Physiol. 266:H1316-H1321.

40. Weyrich, A.S., Ma, X.Y., Lefer, D.J., Albertine, K.H., and Lefer, A.M. 1993. In vivo neutralization of $\mathrm{P}$-selectin protects feline heart and endothelium in myocardial ischemia and reperfusion injury. J. Clin. Invest. 91:2620-2629.

41. Mulligan, M.S., et al. 1992. Neutrophil-dependent acute lung injury: recruitment for P-selectin (GMP-140). J. Clin. Invest. 90:1600-1607.

42. Baeuerle, P.A., and Baltimore, D. 1996. NF-кB: ten years after. Cell. 87:13-20

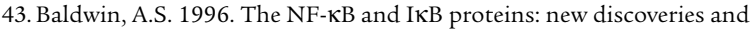
insights. Annu. Rev. Immunol. 14:649-683.

44. Pan, J., Xia, L., Yao, L., and McEver, R.P. 1998. Tumor necrosis factor-or lipopolysaccharide-induced expression of the murine P-selectin gene in endothelial cells involves novel $\mathrm{\kappa B}$ sites and a variant activating transcription factor/camp response element. J. Biol. Chem. 273:10068-10077.

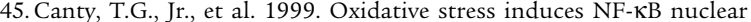
translocation without degradation of I $\kappa \mathrm{B} \alpha$. Circulation. 100(Suppl. II):II361-II-364

46. Palazzo, A.J., Jones, S.P., Anderson, D.C., Granger, D.N., and Lefer, D.J. 1998. Coronary endothelial P-selectin in pathogenesis of myocardial ischemia-reperfusion injury. Am. J. Physiol. 275:H1865-H1872.

47. Anthony, J. 1998. Myocardial ischemia-reperfusion injury in CD-18 and ICAM-1-deficient mice. Am. J. Physiol. 275:H2300-2307.

48. Lefer, D.J., Flynn, D.M., and Buda, A.J. 1996. Effects of a monoclonal antibody directed against P-selectin after myocardial ischemia and reperfusion. Am. J. Physiol. 270:H88-H98.

49. Lefer, D.J., et al. 1993. Cardioprotective actions of a monoclonal antibody against CD-18 in myocardial ischemia-reperfusion injury. Circulation. 88:1779-1787.

50. Ma, X.L., et al. 1993. Monoclonal antibody to L-selectin attenuates neutrophil accumulation and protects ischemic reperfused cat myocardium. Circulation. 88:649-658.

51. Flynn, D.M., Buda, A.J., Jeffords, P.R., and Lefer, D.J. 1996. A sialyl Lewis(x)-containing carbohydrate reduced infarct size: role of selectins in myocardial reperfusion injury. Am. J. Physiol. 271:H2086-H2096.

52. Pan, J., and McEver, R.P. 1995. Regulation of the human P-selectin promoter by bcl-3 and specific homodimeric members of the NF-kB/Rel family. J. Biol. Chem. 270:23077-23083.

53. Manning, A.M., et al. 1995. NF-kappa B is activated during acute inflammation in vivo in association with elevated endothelial cell adhesion molecule gene expression and leukocyte recruitment. J. Inflamm. 45:283-296.

54. Kalra, D., et al. 2000. Nitric oxide provokes tumor necrosis factor-alpha expression in adult feline myocardium through a cGMP-dependent pathway. Circulation. 102:1302-1307.

55. Steven, P.J., et al. 1999. Myocardial ischemia-reperfusion injury is exacerbated in absence of endothelial cell nitric oxide synthase. Am. J. Physiol. 276:H1567-H1573.

56. Saito, Y., et al. 1989. Augmented expression of atrial natriuretic polypeptide gene in ventricle of human failing heart. J. Clin. Invest. 83:298-305. 